spring (April 26, 1932), when growth was already vigorous, the corresponding interval for the same rate of application was two days. There was no appreciable accumulation of nitrate in the soil after any of these applications of sulphate of ammonia.

With nitrate of soda, as might have been expected, the disappearance of the added nitrogen was still more rapid : three-quarters of the nitrate added in an equivalent dressing ( 5 cwt.) on Park Grass had disappeared in about three days in mid-spring, and in late spring less than two days were required.

Without attempting to discuss these results-in particular, the question of what proportion of the nitrogen which disappears is obtained by the plant-they suggest certain practical applications. Evidently the short period during which added nitrogen remains in grassland soils greatly reduces the risk of loss by leaching-out of nitrates, except possibly during the winter months. Where grass is being repeatedly removed, as by mowing or grazing, the direct effect of added nitrogen might be expected to be of brief duration, since evon if it is added as ammonia it does not remain long as a "reserve' in the soil. This very rapid removal of added ammonia by vigorously growing grass-almost as rapid as the removal of nitrate, and a matter of days only-may be taken as a strong indication that in the soil, as well as in culture solutions, grass is able to assimilate ammonia directly without the need for previous nitrification. Further experiments are being made to examine this question.

Chemistry Department,

Rothamsted Experimental Station, Harpenden, Herts, May 27.

\section{Chain Reactions in Enzymatic Catalysis}

Prof. J. B. S. HaLdane has recently criticised the chain reaction theory ${ }^{\mathbf{1}}$ in the form in which it has been applied by Haber and Willstätter to biochemical processes. $^{2}$ One can scarcely deny the validity of Prof. Haldane's arguments, but his criticism is directed not so much against the chain reaction theory itself as against the particular ehain mechanism proposed by Haber and Willstätter.

It has been suggested that a more satisfactory explanation of the experimental observations may be given by the energy chain mechanism. ${ }^{3}$ According to this view, which is due to Christiansen, ${ }^{4}$ molecules are capable of existing in an activated condition which they normally assume prior to reacting, and the chains are propagated by the transfer of energy from the products of an exothermal reaction to one of the reactants, which is thereby activated and in turn caused to react, et seq.

Prof. Willstätter has raised the objection that the activated molecules would at once lose their energy in collisions with the surrounding water molecules. This objection, which at first appears to be conclusive, loses much of its weight in the light of experimental evidence obtained by Gibson and Hinshelwood, ${ }^{5}$ who have shown that the transfer of energy from an activated molecule is a specific process, so that the transfer of energy from organic molecules to water molecules may be taken as being comparatively slight.

Further evidence as to the specificity of cnergytransfer has come from P'orrin's work on fluorescence. ${ }^{b}$ The simple obscrvation that fluorescein fluoresces in aqueous solution shows that the activated fluorescein molecules do not easily give up their energy to the surrounding water molecules, but emit it more readily in the form of light.

As Prof. Haldane has pointed out in this connexion, in most intracellular oxidations much of the energy is not liberated directly as heat but is used up in coupled reactions. This is not easily explained on the Haber and Willstätter mechanism, but the idea of the specific transfer of vibrational energy from the products of an exothermal reaction to other molecules in the system makes these coupled reactions readily intelligible.

'The Christiansen energy-chain talso scems to give a more satisfactory explanation of the specificity of inhibition in enzyme reactions. On this view, inhibition, in so far as it may be attributed to the breaking of reaction chains, is due to the transfer of energy from an activated link-member of the chain to an inhibitor molecule, and this process should also be in some degree specific.

\section{Dyson-Perrins Laboratory, South Parks Road, Oxford.

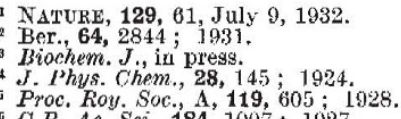

\section{An Unpublished Letter of Lavoisier}

The Science Library at Clifton College possesses an autograph letter of Lavoisier that I believe to be unpublished. Though it is of no scientific importance, any relic of so great a man deserves to be placed on record, and the following transcription may thus be of interest :

Je suis oblige mon cher Parent par le decret relatif a lemprunt forcé de presenter letat de mes possessions et l'evaluation du revenu doit otre faitte dapres la matrice des Rolles. Jo vous scrai en consequence tres oblige de faire faire dans chacune des paroisses ou je possede des biens un extrait de la matrice du rolle pour cequi me conceme avec l'evaluation du revenu. La loi ne donne que quinze jours pour faire les declarations aussy il ny a pas de tems a perdre. Vous concevis que le montant des impositions que je paye ne remplisoit pas mon objet, car en general limpost dans presques toutes les communautés est superieur a "evaluation et puisque la loi a pris pour base cette evaluation il est juste que je proffite du benefice quelle $m$ accorde.

Je ne scais si les haricots ont manque de vos cotes comme aux environs de Paris. Dans letat de denuement ou nous serons cet hiver a Paris pour les comes. tibles, il nous serait fort important que vous nous envoyassicz les haricots de redevance qui me sont dus.

Il y a bien long tems que je n'ay recu de vos nouvelles mais je concois que vous devez etre tres occupe relativement aux requisitions qui ont ete faittes.

Je vous renouvelle mon cher Parent lassurance de mon inviolable attachement.

Le 18 jt 1793 lan $2^{\mathrm{e}}$ de la republique une et indivisible.

LAVOISIER.

The letter is addressed to Citoyen Parisis fils, at Villers-Cotterets, where Lavoisier's paternal ancestors were established as early as the beginning of the seventeenth century. Charlcs-Antoine Parisis was a distant relative of Lavoisier by marriage, having married Antoinette-Francoise Lavoisier, second cousin of Lavoisier's father, Jean-Antoine [Grimaux, Lavoisier, Paris, 1888, p. 326].

Clifton College, Bristol,

\section{E. J. Holmyard.}

No. 3272 , VoL. 130] June 5 . 